\title{
Pre-settlement Snail Fauna on the Sandbanks Baymouth Bar, Lake Ontario, Compared with Nearby Contemporary Faunas
}

\author{
Robert G. Forsyth ${ }^{1,4}$, Paul Catling ${ }^{2}$, Brenda Kostiuk $^{2}$, Sheila McKay-Kuja ${ }^{3}$, and Allen Kuja ${ }^{3}$ \\ ${ }^{1}$ New Brunswick Museum, 277 Douglas Avenue, Saint John, New Brunswick E2K 1E5 Canada \\ ${ }^{2} 170$ Sanford Avenue, Ottawa, Ontario K2C 0E9 Canada \\ ${ }^{3} 11$ Claramount Court, Wellington, Ontario K0K 3L0 Canada \\ ${ }^{4}$ Corresponding author: rforsyth@mollus.ca
}

Forsyth, Robert G., Paul Catling, Brenda Kostiuk, Sheila McKay-Kuja, and Allen Kuja. 2016. Pre-settlement snail fauna on the Sandbanks baymouth bar, Lake Ontario, compared with nearby contemporary faunas. Canadian Field-Naturalist 130(2): $152-157$.

The terrestrial snail fauna in a pre-settlement soil layer, radiocarbon dated at approximately 1065-1560 years old, on the baymouth bar at Sandbanks Provincial Park, Lake Ontario, was compared with 4 nearby contemporary snail faunas from forested dunes. The pre-settlement sample differed in snail diversity, with 23 species compared with 9-20 species in contemporary samples. Six species were unique to the pre-settlement sample: Carychium exile, Euconulus fulvus, Gastrocopta armifera, Gastrocopta corticaria, Vallonia parvula, and Vertigo sp. The number of individual snails was much greater at the pre-settlement site when corrected for difference in size of sample area. The reason for the higher diversity, greater number of individuals, and different fauna associated with the pre-settlement area is unclear, but may be attributed to reduction and changes in the litter layer at the contemporary comparison sites caused by European earthworms. This work suggests that major erosional and depositional events occurred on Great Lakes shoreline dunes in the past and that these can be used to study postglacial mollusc faunas and past ecological processes, with some potentially significant results.

Key Words: Sandbanks baymouth bar; Lake Ontario; land snails; diversity; European earthworms; litter layer

\section{Introduction}

When buried soil layers were found among active dunes with drifting sand and sparse vegetation cover at Sandbanks Provincial Park on the shore of Lake Ontario, it was assumed that they had been buried over the last 200 years following a period of disturbance (tree cutting, overgrazing, and fire), which created drifting sand in early settlement times (Klugh 1912; Tovell 1972; Carlisle et al. 1974; Neugebauer 1974). However, in 1 place the organic layer was $40 \mathrm{~cm}$ thick and composed of at least 3 sublayers that had eroded at different rates, forming shelves. This differential erosion appeared to be the result of differing proportions of sand and organic matter in the sublayers. The deepest sublayer contained charcoal. We speculated that the forest at this site had burned, then been covered by a thin layer of sand, and that forest had then redeveloped. As this would likely have required more than a few hundred years, the layer might substantially predate European settlement, suggesting ecological processes of fire and sand movement at much earlier times. Embedded among the vertical erosional layers were the exposed subfossil shells of terrestrial snails, which we suggest occupied a former deciduous forest, as coniferous forest and other successional vegetation on dunes in the region are associated with a very limited terrestrial snail fauna.

Here, we establish the date of these buried soil layers as pre-European and compare their terrestrial snail fauna with nearby contemporary snail faunas in woodland on dunes. Such comparison may provide information on historical changes and enable a better understanding of the impact of foreign soil and litter organisms. These include European earthworms and other introduced soil fauna that may have had profound impacts on litter and substrate in deciduous forest (Frelich et al. 2006; MiggeKleian 2006). We speculate that pre-European-settlement snail faunas would have been more diverse, existed at higher densities, and differed in composition as a result of the deeper and more complex surface litter that existed at that time.

\section{Study Area}

Baymouth bar

The baymouth bar at Sandbanks Provincial Park is one of the largest freshwater baymouth bars in the world (Ainsworth et al. 2012). It extends from Wellington to West Point, a distance of $8 \mathrm{~km}$. Much of the area is a mixture of grassland with American Beachgrass ( $\mathrm{Am}$ mophila breviligulata Fernald), scrub including Bayberry Willow (Salix myricoides Muhl.), Riverbank Grape (Vitis riparia Michx.), and Sand Cherry (Prunus pumila L.), and shallow pools with Smooth Twig-rush (Cladium mariscoides (Muhl.) Torrey). The likely pre-settlement sampling area, $43.9218^{\circ} \mathrm{N}, 77.2947^{\circ} \mathrm{W}$ (Figure 1) is part of a series of perched dunes (dunes that sit on a plateau above the shore) that are $400 \mathrm{~m}$ from the front dune on the Lake Ontario shore and approximately $20 \mathrm{~m}$ above the Lake Ontario shoreline.

We believe that the pre-settlement site is not an assemblage resulting from deflation, i.e., erosion of ver- 


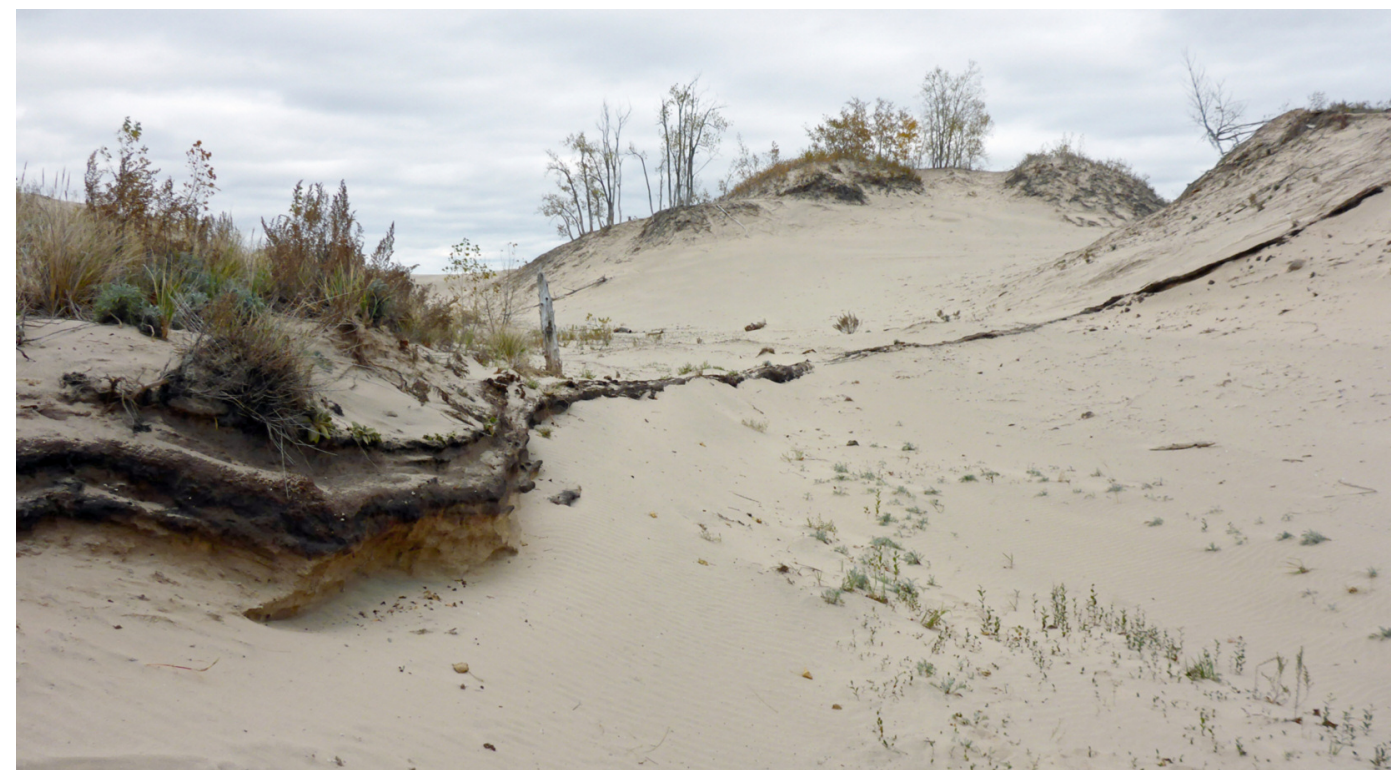

FIGURE 1. Buried soil layer sampled (the lower of 3 layers seen on the left) in dunes on the baymouth bar at Sandbanks Provincial Park, Ontario. The vertical exposure of soil forms an irregular circle remaining after the top of a hill was eroded. The sand erodes more readily than the soil, leaving a depression surrounded by a low ridge. Only part of this is seen in the photo. Photo: Brenda Kostiuk.

tical layers and transport to new horizontal layers, where shells would be concentrated and overall represent relatively long average times. An allochthonous (transported) assemblage would be less likely to include both light (organic material and small shells) and heavy material (such as adult Neohelix shells $30 \mathrm{~mm}$ across) juxtaposed but widespread. The assumption of forest burial was a key element in this investigation, so a literature search was undertaken to determine if this was likely.

\section{Comparison sites}

The current open dunes and early successional communities that include conifers are largely devoid of snails. For this reason, in the past, terrestrial molluscs must have occurred mostly in dunes vegetated with deciduous woods, as they do today. Thus, the pre-settlement snail assemblage under study here is assumed to have occurred in the only dune community hosting substantial terrestrial snail populations, that being deciduous forest.

Having decided this, the contemporary sites selected for sampling were all deciduous forest on dunes. All were within $4 \mathrm{~km}$ of our pre-European site: (1) approximately $43.9038^{\circ} \mathrm{N}, 77.2663^{\circ} \mathrm{W}$, mature woodland dominated by Sugar Maple (Acer saccharum Marshall), White Ash (Fraxinus americana L.), Basswood (Tilia americana L.), and Trembling Aspen (Populus tremuloides Michx.); (2) $43.8981^{\circ} \mathrm{N}, 77.2187^{\circ} \mathrm{W}$, mature woodland dominated by Sugar Maple, Black
Maple (Acer nigrum Michx.), Basswood, and White Ash; (3) $43.8926^{\circ} \mathrm{N}, 77.2140^{\circ} \mathrm{W}$, successional woodland of Eastern White Cedar (Thuja occidentalis L.), Trembling Aspen, White Pine (Pinus strobus L.), Paper Birch (Betula papyrifera Marshall), and poplars (Populus spp.); (4) $43.9043^{\circ} \mathrm{N}, 77.2313^{\circ} \mathrm{W}$, same woodland as site 3 .

\section{Methods \\ Accelerator mass spectrometry}

Because knowledge of the pre-settlement age is essential to the concept presented here, we support it with radiocarbon dating using accelerator mass spectrometry (AMS). This process accelerates ions to high kinetic energies before mass analysis, enabling separation of rare carbon isotopes. The age of organic material can be determined by relative abundance of isotopes (based on rate of decay), such as radioactive carbon $\left({ }^{14} \mathrm{C}\right)$. AMS analysis was done by Beta Analytic Inc. (Miami, Florida, USA) on a shell of Neohelix albolabris (Say, 1817), Whitelip, and a fragment of charcoal, both from $37 \mathrm{~cm}$ depth in the series of soil layers. The shell was pretreated with acid to reduce contamination. The charcoal was pretreated with acid/alkali/acid wash to remove carbonates, remove organic acids, and neutralize alkali, respectively. The measured radiocarbon ages were corrected for total isotopic fractionation effects, resulting in a conventional radiocarbon age and this was calibrated for past variance in ${ }^{12} \mathrm{C}$ to ${ }^{14} \mathrm{C}$ ratios using the 
IntCal 13 database (Talma and Vogel 1993; Reimer et $a l$. 2013). The results were calendar-calibrated and reported as years before present (BP, i.e., before 1950 as is standard practice).

\section{Collection and identification of samples}

At the site of the buried soil layer, snails were sampled in October 2014 and April 2015 on an exposed vertical face of buried organic layers surrounding a blowout (Figure 1). The sampling was carried out in 4 adjacent $3 \mathrm{~m}$ lengths, $35-40 \mathrm{~cm}$ below the uppermost organic layer. This represented the $37-\mathrm{cm}$ depth that was dated. The total area of the face for the sampling of the organic layer was $6000 \mathrm{~cm}^{2}$, as this was all that was available at the time. Snails were apparent in the face as a result of dark organic material being eroded around them. Only shells visible on the face were collected.

Each of the 4 contemporary comparison sites included a sampled area of $10000 \mathrm{~cm}^{2}$ per quadrat $\times 10$ quadrats for a total of $100000 \mathrm{~cm}^{2}$. In each quadrat, $30 \mathrm{~min}-$ utes was spent searching litter and the soil surface. Most snails were found in the first 10 minutes of search in the thin leaf litter, which was composed largely of leaves and leaf fragments from the previous year. Following this, the uppermost few millimetres of harder packed organic soil was also searched for snails of all sizes down to $1 \mathrm{~mm}$ diameter. Again, most snails were found in the first 10 minutes. Very few, if any, snails were found in the final 10 minutes of search, suggesting that the search was complete. Only visual search techniques were used; there was no collection or subsequent examination of litter samples. The survey was carried out in late April and early May 2015 when snails were active. Numbers of both living and dead species were recorded in each quadrat and tallied to provide a sample of species and their numbers at each site. We collected all snails in each area (quadrat or vertical face) so that samples would be quantitative and approximately comparable.

Identifications were made using Pilsbry (1939, 1940, 1946, 1948), Burch (1962), and Grimm et al. (2010). Specimens that were immature, broken, or too worn to identify to species, but for which identification to genus was possible, were designated "sp." Specimens of Polygyridae (Mesodon thyroidus or Neohelix albolabris), consisting of small fragments and juveniles, for which the genus and species were undeterminable, were recorded as "immature polygyrids." Subfossil and contemporary specimens were deposited in the collections of the Geology and Zoology sections, respectively, of the New Brunswick Museum.

\section{Simple comparison and area correction}

The numbers of species and individual snails at the pre-settlement site and each of the comparison sites were compared. Material not identified to species was omitted to prevent potential double-counting of a taxon. This omission made little difference because such instances were relatively few and generally involved few individuals.

The face of the pre-settlement sampling site was $1 / 16.7$ the size of each of the sampled areas of the comparison sites; thus, it may be expected to be much poorer in diversity and smaller in population size. Beyond a certain level, there may be limits to diversity regardless of area size. However, the number of individuals may be expected to increase linearly with sample area; thus, a correction between number of individuals and size of area sampled is not unreasonable. For the horizontal surfaces of the comparison sites to be comparable to the vertical pre-settlement sample the following assumptions were necessary.

(1) Snail densities are equally distributed throughout the pre-settlement volume (as a result of an equal rate of deposition). This pre-settlement volume may represent as much as 50 years (based on 1 year of horizontal deposition per millimetre) or as little as 5 years. Regardless, if snail faunas vary in density, diversity, and composition over time, it must be assumed that the variation is minimal. This assumption is necessary because the comparison sites are snapshots of an instant in time (i.e., a few years), and the pre-settlement assemblage might appear more diverse and abundant simply by representing specimens from a longer period of time (i.e., many decades).

(2) The vertical and horizontal situations are similarly easy to sample. In fact the vertical subfossil-bearing face was easier to sample because the size of the organic material was not as variable and the shells were white and easily seen. However, the decline in new snails discovered in the first 30 minutes in the horizontal comparison plots suggested that the inventory was nearly complete.

(3) The surface areas are known. This was not entirely the case because the horizontal comparison plots had more surface area in terms of leaves and sticks and may have contained more snails as a result. Nevertheless, the excess surface area may be equivalent to less than $1 \mathrm{~mm}$ in the vertical sample and, if so, the comparison is reasonable.

(4) The current populations in the horizontal comparison plots are all destined for preservation as occurred in the pre-settlement sample, where calcium carbonate in the sand may have aided shell preservation. In fact a smaller number may reach the preservation stage because of predation and destruction by mammals and birds. However, predation existed in the past as well. Another associated concern is that living snails are being compared with dead snails. It is true that the horizontal comparison plots included living snails, but these amounted to less than $5 \%$ of the samples.

Although weighing these considerations does not provide any definite way of correcting for area, we suggest that a correction for area to create a range by multiplying the number of individuals at the pre-settlement site by the factor by which the comparison sites are 
larger (16.7) is informative as long as the limitations are understood.

\section{Results}

\section{Likelihood of forest burial}

Regardless of recent events that led to erosion, drifting sand, and forest burial, there is reason to believe that forest burial occurred in pre-settlement times. As archaeological material is scarce at Sandbanks and because of the location between historical warring Huron and Iroquois peoples (Neugebauer 1974), strong evidence that indigenous peoples played a significant role in vegetation development in the area is lacking. Thus, there is reason to believe that forest burial occurred through natural processes. Buried soils in a perched dune field serve as indicators of a late Holocene change in lake level on the Lake Superior shore (Anderton and Loope 1995). On Lake Michigan, high lake levels have been shown to destabilize coastal bluffs making sand available to leeward-perched dunes on a cycle of approximately 150 years. During high lake levels, forest is buried, but lower levels and relative sand starvation permit forestation and soil development on the dunes (Chrzastowski et al. 1991; Loope and McEachern 1998; Loope and Arbogast 2000).

All that is required to bury forests on perched dunes along the shore of Lake Ontario is fluctuating water levels and the factors that cause them. Overall the level of Lake Ontario has risen since 11500 years BP when the lake was formed in postglacial times (McCarthy and McAndrews 1988). However, there is much evidence for fluctuation superimposed on this general trend. Fluctuation occurred in the early postglacial time (Jackson et al. 2000), and, much later (3000-2100 years BP), there were also periods of rapid rise in water level related to episodes of relatively cool, wet climate (McCarthy and McAndrews 1988). Also superimposed on the general rising trend, Flint et al. (1988) reported oscillations over the past 3300 years, with an amplitude in the order of $1 \mathrm{~m}$ over several hundred years. These oscillations have also been related to longer-term climate changes (McCarthy 1986). More recently, small-scale fluctuations in water level have occurred (Kunkel et al. 2013): for example, a period of high levels between 1941 and 1954 following a period of low water level from 1930 to 1940 . These fluctuations are also associated with climate, with cooler, wetter periods producing the higher levels. Thus, the climatic variations responsible for fluctuations in water level in Lake Ontario over the past several thousand years and the fluctuations themselves are evident. Consequently evidence for the periodic burial of forests on perched dunes is to be expected.

\section{Dating}

Radiocarbon analysis of material in the organic layer resulted in a date of 1190-1065 BP for the charcoal (Beta 396269) and 1560-1410 BP for the partial shell of Neohelix albolabris (Beta 396270). The "reservoir effect" is the tendency for shells to appear older than they are as a result of incorporating old limestone, which is depleted of ${ }^{14} \mathrm{C}$. Although this effect may be insignificant for smaller shells (Pigati et al. 2010), Neohelix is relatively large (about $30 \mathrm{~mm}$ in diameter) and, thus, we consider the charcoal dates to be more reliable.

\section{Survey results}

All sites had unique species, and the numbers of species varied among sites. The pre-settlement site had the greatest snail diversity, with 23 species, including a number that did not occur in the comparison sites: Carychium exile, Euconulus fulvus, Gastrocopta armifera, Gastrocopta corticaria, Vallonia parvula, and Vertigo sp. (Table 1). Without correcting for area, the pre-settlement sample had 161 individual snails and the comparison sites had 27 to 352 (Table 1). Using the correction factor, the pre-settlement sample had 2684 individuals. Thus the pre-settlement sample not only had higher diversity and distinct composition, but also the greatest number of snails.

\section{Discussion}

Periodic burial of forest on dunes is to be expected, and dating of apparent burial in this case suggested that the buried layer from which the snails were obtained preceded the arrival and settlement of Europeans in the Great Lakes region (i.e., after 1600 or 335 BP). Consequently, the samples are appropriate for a comparison of pre-settlement and post-settlement faunas.

The variation in the snail assemblages at the comparison sites suggests that none can be considered representative of the snail fauna that existed in any larger area at any particular time. This applies also to the presettlement site, which is simply a snapshot of a past fauna. This does not prevent comparisons; it simply means that the comparison has limits in broad application and the results can only be viewed as evidence of a local phenomenon.

The different composition, higher diversity, and greater snail density of the pre-settlement sample suggests that conditions may have been different at that time. We speculate that the soil's upper organic horizon was much thicker and this hosted higher diversity, different species, and larger numbers of snails. A decline (sometimes total elimination) of the $\mathrm{O}$ horizon has been associated with invasion by European earthworms (e.g., Hale et al. 2005, 2008), and this affects a variety of forest floor animals (e.g., Frelich et al. 2006; MiggeKleian et al. 2006; Schlaghamersky et al. 2014). Although there are no studies that specifically point to declines in terrestrial molluscs as a result of invasive earthworms, this seems likely (Norden 2010); our own casual observations in other deciduous woods in southern Ontario seem to suggest this. Other foreign animals were also frequent in the comparison sites, including predacious ground beetles, pill bugs, and slugs, which may also have negatively affected native snails, leading to lower diversity and density than before their introduction from Europe. 
TABLE 1. Species of terrestrial snails and summary of diversity found in buried, pre-settlement, organic layers on the baymouth bar at Sandbanks Provincial Park, Ontario, and 4 contemporary woodland sites. To avoid double-counting, numbers of specimens in parentheses were not included in total number of species for some sites.

\begin{tabular}{|c|c|c|c|c|c|}
\hline \multirow[b]{2}{*}{ Species } & \multirow{2}{*}{$\begin{array}{l}\text { Pre-settlement } \\
\text { site }\end{array}$} & \multicolumn{4}{|c|}{ Contemporary sites } \\
\hline & & 1 & 2 & 3 & 4 \\
\hline Anguispira alternata (Say, 1817), Flamed Tigersnail & 6 & 4 & 7 & 1 & \\
\hline Carychium exile H.C. Lea, 1842, Ice Thorn & 1 & & & & \\
\hline Cepaea sp. & & & 1 & & \\
\hline Cochlicopa lubrica (Müller, 1774), Glossy Pillar & 3 & 45 & 1 & & 48 \\
\hline Columella edentula (Draparnaud, 1805), Toothless Column & & 3 & 2 & & \\
\hline Discus catskillensis (Pilsbry, 1896), Angular Disc & 8 & 88 & & & \\
\hline Euchemotrema fraternum (Say, 1824), Upland Pillsnail & 1 & 16 & 37 & & \\
\hline Euconulus fulvus (Müller, 1774), Brown Hive & 1 & & & & \\
\hline Euconulus polygyratus (Pilsbry, 1899), Fat Hive & 4 & 27 & 4 & 6 & \\
\hline Gastrocopta armifera (Say, 1821), Armed Snaggletooth & 4 & & & & \\
\hline Gastrocopta contracta (Say, 1822), Bottleneck Snaggletooth & 16 & 22 & & 1 & \\
\hline Gastrocopta corticaria (Say, 1816), Bark Snaggletooth & 1 & & & & \\
\hline Gastrocopta holzingeri (Sterki, 1889), Lambda Snaggletooth & 5 & & 2 & 1 & 1 \\
\hline Gastrocopta pentodon (Say 1822), Comb Snaggletooth & 1 & 3 & 1 & & \\
\hline Glyphyalinia indentata (Say 1823), Carved Glyph & 1 & 10 & 11 & 9 & 1 \\
\hline Glyphyalinia rhoadsi (Pilsbry 1899), Sculpted Glyph & & 7 & & & \\
\hline Haplotrema concavum (Say, 1821), Grey-foot Lancetooth & & 1 & 4 & & \\
\hline Hawaiia minuscula (A. Binney, 1841), Southeastern Gem & 23 & 8 & 2 & 1 & 2 \\
\hline Helicodiscus parallelus (Say, 1817), Compound Coil & 5 & & 3 & 3 & 2 \\
\hline Mesodon thyroidus (Say, 1817), White-lip Globe & & 47 & & & \\
\hline Neohelix albolabris (Say, 1817), Whitelip & 2 & 9 & 88 & 2 & \\
\hline Nesovitrea binneyana (Morse, 1864), Blue Glass & 4 & 12 & & & \\
\hline Nesovitrea $\mathrm{sp}$. & (3) & & 1 & & \\
\hline Punctum minutissimum (I. Lea, 1841), Small Spot & 1 & 3 & & & \\
\hline Pupilla muscorum (Linnaeus, 1758), Widespread Column & & & & 1 & 1 \\
\hline Strobilops labyrinthicus (Say, 1817), Maze Pinecone & 39 & 17 & & 2 & 2 \\
\hline Vallonia costata (Müller, 1774), Costate Vallonia & & & & 28 & \\
\hline Vallonia gracilicosta Reinhardt, 1883 , Multirib Vallonia & 25 & 1 & & & \\
\hline Vallonia parvula Sterki, 1893 , Trumpet Vallonia & 3 & & & & \\
\hline Vertigo sp. & 3 & & & & \\
\hline Vitrina angelicae Beck, 1837, Eastern Glass-snail & & 38 & & & 1 \\
\hline Zonitoides nitidus (Müller, 1774), Black Gloss & & 10 & 5 & & 3 \\
\hline Zonitoides sp. & 9 & (3) & & & 1 \\
\hline Immature Polygyridae & $(5)$ & $(16)$ & & (1) & \\
\hline Total no. species & 23 & 20 & 15 & 11 & 10 \\
\hline Total no. specimens & $161-2684 *$ & 352 & 169 & 27 & 89 \\
\hline
\end{tabular}

* Corrected for area.

The interpretation of results presented here rests on many assumptions, making the comparison and explanation little more than a partly supported hypothesis. Regardless of the extent or cause of the difference, it appears that major erosional and depositional events occurred on Great Lakes shoreline dunes in the past and that they can be used to study postglacial mollusc faunas and past ecological processes with some possibly significant results. The success of such an endeavour will depend on the extent to which methods can be developed to reduce assumptions and extend results.

\section{Acknowledgements}

Dr. Timothy Pearce, Carnegie Museum of Natural History, and an anonymous reviewer, provided useful comments on the manuscript.

\section{Literature Cited}

Ainsworth, P., Y. Bree, J. Childs, and J. Dewey. 2012. Sandscapes: Exploring the Dunes of Sandbanks Provincial Park. Friends of Sandbanks, Picton, Ontario, Canada.

Anderton, J. B., and W. L. Loope. 1995. Buried soils in a perched dunefield as indicators of late Holocene lake level change in the Lake Superior basin. Quaternary Research 44: 190-199.

Burch, J. B. 1962. How to Know the Eastern Land Snails. Wm. C. Brown, Dubuque, Iowa, USA.

Carlisle, R. J., M. Whitcombe, and R. Harris. 1974. An ecological assessment of Prince Edward County: with special reference to the Sandbanks/Outlet Beach area. Ontario Ministry of Natural Resources, Toronto, Ontario, Canada.

Chrzastowski, M. J., F. A. Pranschke, and C. W. Shabica. 1991. Discovery and preliminary investigations of the remains of an early Holocene forest on the floor of southern Lake Michigan. Journal of Great Lakes Research 17: 543 552. 
Flint, J. E., R. W. Dalrymple, and J. J. Flint. 1988. Stratigraphy of the Sixteen Mile Creek Lagoon and its implications for Lake Ontario, Canada, water levels. Canadian Journal of Earth Sciences 25: 1175-1183.

Frelich, L. E., C. M. Hale, S. Scheu, A. R. Holdsworth, L. Heneghan, P. J. Bohlen, and P. B. Reich. 2006. Earthworm invasion into previously earthworm-free temperate and boreal forests. Biological Invasions 8: 1235-1345.

Grimm, F. W., R. G. Forsyth, F. W. Schueler, and A. Karstad. 2010. Identifying Land Snails and Slugs in Canada: Introduced Species and Native Genera. Canadian Food Inspection Agency, Ottawa, Ontario, Canada.

Hale, C. M., L. E. Frelich, P. B. Reich, and J. Pastor. 2005. Effects of European earthworm invasion on soil characteristics in northern hardwood forests of Minnesota, USA. Ecosystems 8: 911-927.

Hale, C. M., L. E. Frelich, P. B. Reich, and J. Pastor. 2008. Exotic earthworm effects on hardwood forest floor, nutrient availability and native plants: a mesocosm study. Oecologia 155: 509-518.

Jackson, L. J., C. Ellis, A. V. Morgan, and J. H. McAndrews. 2000. Glacial lake levels and eastern Great Lakes paleo-indians. Geoarchaeology 15: 415-440.

Klugh, A. B. 1912. The flora of the sand dunes of Prince Edward County. Ontario Natural Science Bulletin 7: 40-51.

Kunkel, K. E., L. E. Stevens, S. E. Stevens, L. Sun, E. Janssen, D. Wuebbles, J. Rennells, A. Gaelano, and J. G. Robson. 2013. Regional climate trends and scenarios for the U.S. National Climate Assessment. Part 1. Climate of the northeast U.S. Technical report NESDID 142-1. National Oceanic and Atmospheric Administration, Silver Spring, Maryland, USA. Accessed December 2014. http:// tinyurl.com $/ \mathrm{hj} 7 \mathrm{cb} 9 \mathrm{o}$.

Loope, W. L., and A. F. Arbogast. 2000. Dominance of a $\sim 150$-year cycle of sand-supply change in late Holocene dune-building along the eastern shore of Lake Michigan. Quaternary Research 54: 414-422.

Loope, W. L., and A. K. McEachern. 1998. Habitat change in a perched dune system. Pages 227-230 in Status and Trends of the Nation's Biological Resources, Volume 1. Edited by M. J. Mac, P. A. Opler, C. E. Puckett, and P. D. Doran. United States Geological Survey, Reston, Virginia, USA.

McCarthy, F. 1986. Late Holocene water levels in Lake Ontario: evidence from Grenadier Pond. M.Sc. thesis, University of Toronto, Toronto, Ontario, Canada.

McCarthy, F. M., and J. H. McAndrews. 1988. Water levels in Lake Ontario 4230-2000 years B.P.: evidence from Grenadier Pond, Toronto, Canada. Journal of Paleolimnology 1: 99-113.
Migge-Kleian, S., M. A. McLean, J. C. Maerz, and L. Heneghan. 2006. The influence of invasive earthworms on indigenous fauna in ecosystems previously uninhabited by earthworms. Biological Invasions 8: 1275-1285.

Neugebauer, J. 1974. Land use history, landscape change, and resource conflict in the Sandbanks Provincial Park area, Prince Edward County. M.A. thesis, University of Western Ontario, London, Ontario, Canada.

Norden, A. W. 2010. Invasive earthworms: a threat to eastern North American forest snails? Tentacle 18: 29-30.

Pigati, J. S., J. A. Rech, and J. C. Nekola. 2010. Radiocarbon dating of small terrestrial gastropod shells in North America. Quaternary Geochronology 5: 519-532.

Pilsbry, H. A. 1939. Land Mollusca of North America (North of Mexico), Volume 1, Part 1. Monographs 3. Academy of Natural Sciences of Philadelphia, Philadelphia, Pennsylvania, USA.

Pilsbry, H. A. 1940. Land Mollusca of North America (North of Mexico), Volume 1, Part 2. Monographs 3. Academy of Natural Sciences of Philadelphia, Philadelphia, Pennsylvania, USA.

Pilsbry, H. A. 1946. Land Mollusca of North America (North of Mexico), Volume 2, Part 1. Monographs 3. Academy of Natural Sciences of Philadelphia, Philadelphia, Pennsylvania, USA.

Pilsbry, H. A. 1948. Land Mollusca of North America (North of Mexico), Volume 2, Part 2. Monographs 3. Academy of Natural Sciences of Philadelphia, Philadelphia, Pennsylvania, USA.

Reimer, P. J., E. Bard, A. Bayliss, J. W. Beck, P. G. Blackwell, C. B. Ramsey, C. E. Buck, H. Cheng, R. L. Edwards, M. Friedrich, P. M. Grootes, T. P. Guilderson, H. Haflidason, I. Hajdas, C. Hatté, T. J. Heaton, D. L. Hoffmann, A. G. Hogg, K. A. Hughen, K. F. Kaiser, B. Kromer, S. W. Manning, M. Niu, R. W. Reimer, D. A. Richards, E. M. Scott, J. R. Southon, R. A. Staff, C. S. M. Turney, and J. van der Plicht. 2013. IntCal 13 and Marine 13 radiocarbon age calibration curves $0-50,000$ years cal BP. Radiocarbon 55: 1869-1887.

Schlaghamersky, J., N. Eisenhauer, and L. E. Frelich. 2014. Earthworm invasion alters enchytraeid community composition and individual biomass in northern hardwood forests of North America. Applied Soil Ecology 83: 159-169.

Talma, A. S., and J. C. Vogel. 1993. A simplified approach to calibrating ${ }^{14} \mathrm{C}$ dates. Radiocarbon 35 : 317-322.

Tovell, W. M. 1972. The Sandbanks. Ontario Ministry of Natural Resources, Toronto, Ontario, Canada.

Received 17 November 2015

Accepted 1 May 2016 